\title{
Estratégias de expropriação e contratos de trabalho na cafeicultura Paulista (1917-1937)
}

Rogério Naques Faleiros*

Resumo: Este artigo objetiva compreender as relações de trabalho estabelecidas nas lavouras de café entre fazendeiros e trabalhadores rurais (genericamente chamados de colonos) no período de 1917 a 1937, no qual, em função da intervenção governamental no mercado cafeeiro (as defesas do café) e da existência de uma legislação altamente vulnerável no que se referia à apropriação de terras em grande escala nas zonas novas, se verificou um rápido processo de expansão da fronteira agrícola no estado de São Paulo, Brasil. Utilizamos como principal fonte documental duas mil e quarenta e sete escrituras de contratos de formação e trato de cafezais lavradas em quatorze municípios do interior paulista.

Palavras-chave: fronteiras, complexo cafeeiro, contratos.

Abstract: we aim to understand the working relationship established in coffee plantations between farmers and farmworkers (generically called colonos) between 1917 and 1937, during which, as a function of government intervention in the market coffee and the existence of a highly vulnerable legislation regarding the ownership of lands on a large scale in new areas, there was a rapid expansion of the agricultural frontier in São Paulo State, Brazil. We use as the main source documentary 2,047 Scriptures training contracts and tract of coffee plantations recorded in fourteen cities of São Paulo.

Keywords: frontier, coffee economy, contracts.

\section{Introdução}

Em função das conhecidas intervenções do governo brasileiro no mercado de café e de uma legislação altamente vulnerável no que se referia à apropriação (legal ou ilegal) de terras em São Paulo, a fronteira agrícola avançou nesse estado num ritmo, até então, sem precedentes na história nacional. Nos vinte anos compreendidos entre 1917 e 1937, assistiu-se no chamado "oeste paulista" o vil espetáculo do extermínio indígena mediante a ação dos bugreiros (nomenclatura dada aos homens que se especializaram na matança do gentio), das recorrentes trapaças, que

* Departamento de Economia e Programa de Pós-Graduação em Política Social/UFES. Contato: rogerio. faleiros@ufes.br 
do nada criavam escrituras, comprovando a antiga propriedade sobre a terra, e que como mágica estabeleciam fazendas nas matas cerradas nunca dantes visitadas pelo "homem branco". Verifica-se também, no início do século XX, a expansão das estradas de ferro para aquelas regiões, bem como o vigoroso aumento das cargas transportadas, o que anunciava o desenvolvimento de uma nova civilização nas distantes paragens.

À época, uma gigantesca pletora de capitais direcionou-se à fronteira em busca de realização, ampliando os padrões de acumulação vigentes nas terras já ocupadas pela cafeicultura, situadas a Leste. Nas áreas novas, formaram-se lavouras de café que demandariam uma quantidade ainda maior de mão de obra. Seguiam-se ao capital e aos fazendeiros os colonos ${ }^{1}$ do café, com destaque para os contingentes espanhóis, portugueses, italianos e japoneses, que doravante viveriam no inferno das fronteiras, motivados pelo sonho de uma vida melhor. A que tipo de relações de trabalho as pessoas que se dirigiram para as novas áreas de expansão da cafeicultura, para as fronteiras do café, foram submetidas?

É justamente essa a questão que procuraremos responder neste artigo, mediante o trabalho com duas mil e quarenta e sete escrituras de contratação de mão de obra registradas em cartórios de quatorze municípios situados em diversas regiões do estado de São Paulo nos marcos da periodização proposta. São eles: Campinas, Rio Claro, Ribeirão Preto, Franca, São Carlos, Araraquara, Botucatu, São Manuel, Jaú, Novo Horizonte, São José do Rio Preto, Catanduva, Lins e Pirajuí. Evidentemente, é impossível traçar interpretações cerradas sobre os destinos dos trabalhadores rurais do complexo cafeeiro, pois sempre há casos muito específicos e experiências de vida que contrariam tanto as teses que preconizam maiores possibilidades de ascensão social à condição de proprietários rurais quanto as que indicam um universo marcado por um alto grau de exploração da mão de obra. Na verdade, as chances dos colonos dependiam de um amplo conjunto de variáveis que iam desde o período de chegada ao Brasil, de crise ou de expansão da cafeicultura, até as qualidades dos solos trabalhados, o número de membros que compunham a família, os preços praticados em determinadas ocasiões, o tipo de contrato ao qual seriam submetidos e a região para a qual se dirigiriam. Mesmo num universo em que qualquer resposta à questão colocada pode ser temerária, arriscamo-nos aqui a defender a hipótese de que existiam grandes obstáculos à ascensão social ao conjunto dos trabalhadores, obstáculos esses próprios de uma sociedade extremamente marcada pela desigualdade social, tal como a brasileira. Façamos antes um breve comentário sobre as fontes documentais disponíveis e sobre as principais interpretações referentes a essa questão, para posteriormente discutirmos as fontes documentais pesquisadas (Os Livros Cartoriais) e apontarmos as nossas considerações finais.

\section{Um breve comentário sobre as fontes disponíveis ao estudo das relações de trabalho no complexo cafeeiro}

O pesquisador que se interessar pelo estudo das relações de trabalho travadas na cafeicultura paulista terá algumas evidências documentais à sua disposição. Uma das primeiras fontes utilizadas no estudo dessa questão foram os jornais que

1 A nomenclatura "colono" aqui designa a totalidade dos trabalhadores rurais alocados na cafeicultura paulista, não se referindo unicamente aos trabalhadores submetidos às relações de colonato. 
circulavam nas principais cidades do país, tais como o Fanfulha. O trabalho com esse tipo de fonte sempre exige certo cuidado por parte do pesquisador, uma vez que muitos desses veículos de informação eram dominados ora por membros da elite cafeeira, ora por pessoas ligadas à "causa imigrante", tendendo as interpretações dos fatos, respectivamente, a uma visão "benéfica" ou "cruel” em relação à condição de vida dos trabalhadores. De qualquer forma, as fontes impressas cumpriram importante missão na divulgação de dados atinentes ao que ocorria nas lavouras de café, no que se refere à relação entre empregadores e empregados.

As estatísticas e os relatórios governamentais, sobretudo as estatísticas organizadas pelo Departamento Estadual do Trabalho, criado em 1911, também fornecem aos pesquisadores algumas informações preciosas sobre o tema em tela, entretanto, há que se fazer uma ressalva a essas fontes, pois se tratam de documentos oficiais produzidos com o claro intuito de mascarar as vicissitudes impelidas às famílias de trabalhadores alocados nas fazendas de café. O fato é que a partir de 1902, ano no qual Giulio Prinetti - chefe do Comissariado Geral da Emigração na Itália - proibiu a emigração subvencionada para o Brasil, inúmeros documentos oficiais foram produzidos pelo governo brasileiro e circularam internacionalmente, procurando ressaltar a "excelente" condição de vida proporcionada pela labuta nas lavouras aos italianos e aos trabalhadores em geral, de modo que debruçar-se incautamente sobre esses registros pode levar o pesquisador a aproximações não fidedignas, prejudicando sua análise. ${ }^{2}$

As correspondências enviadas pelos imigrantes aos seus países de origem constituem importante registro para o estudo das relações de trabalho na cafeicultura paulista. $O$ estudo de Chiara Vangelista ${ }^{3}$ valeu-se de algumas cartas enviadas à Itália por imigrantes, nas quais encontrou relatos que ora vangloriavam as condições de vida na fazenda, convidando os compatriotas a aventurarem-se na América, e ora denunciavam as dificuldades existentes na realidade rural. Certamente, essas correspondências traziam algumas informações sobre poupanças, salários e outras remunerações, sendo estas informações de grande relevância ao estudo da questão do trabalho nas fazendas de café. $O$ trabalho de Alves ${ }^{4}$ também evidenciou a importância das cartas como fonte histórica, ao tratar das correspondências enviadas por imigrantes alemães sediados no Rio de Janeiro em meados do século XIX.

O trabalho de Alvim5, cujo objetivo era o estudo da vida privada de imigrantes sediados nas fazendas de café, também trouxe importante contribuição para o entendimento do trabalho e das condições da mão de obra no campo, atentando para as possibilidades de estudos sobre o cenário rural que considerem as condições de moradia, de higiene pessoal, de alimentação, de religiosidade e de representações. O texto nos permite pensar nas potencialidades de utilização de novas fontes históricas para o entendimento das relações de trabalho travadas naquele universo, tais como os objetos e as anotações pessoais, as fotografias, os hábitos e as celebrações.

2 Ver o trabalho de Thomas Holloway (1984), especialmente o capítulo n. 04, onde são demonstradas fontes desta natureza.

3 VANGELISTA, Chiara. Os Braços da lavoura. Imigrantes e "caipiras" na formação do mercado de trabalho paulista (1850-1930). São Paulo: Hucitec; Instituto Italiano di Cultura; Instituto Cultural Ítalo-Brasileiro, 1991.

4 ALVES, Débora Bendocchi. Cartas de imigrantes como fonte para o historiador: Rio de Janeiro - Turíngia (1852-53). São Paulo, Revista Brasileira de História, v. 23, n. 45, 2003.

5 ALVIM, Zuleika. Imigrantes: a vida privada dos pobres no campo. In: NOVAIS, Fernando. História da vida privada no Brasil. v. 03. São Paulo: Cia. das Letras, 1998. 
Os trabalhos de Benincasa ${ }^{6}$ e Ferrão7, que reconstituem a "arquitetura" das fazendas em Araraquara e Campinas, respectivamente, reúnem potencialidades para a discussão das relações de trabalho na cafeicultura, uma vez que, considerando a estrutura física instalada e a modernização das unidades produtoras, podemos discutir as formas pelas quais os fazendeiros a utilizavam para ampliar o grau de exploração dos colonos. Nas fazendas que possuíam plantas mais completas, formadas por tulhas, casa de máquina, terreiros e estradas, os trabalhadores se viam obrigados a pagar taxas pela utilização dessa estrutura, pressionando ainda mais seus rendimentos monetários e não monetários.

O alargamento das fontes históricas possibilitado pelas tendências, métodos e abordagens historiográficas da chamada terceira geração dos "Analles", e que vem amadurecendo ao longo das últimas décadas, possibilitou uma utilização mais padronizada e ampla da história oral. Os depoimentos colhidos com os atores da economia cafeeira podem render resultados extraordinários, tais como os obtidos por Sallum Júnior ${ }^{8}$, que em sua pesquisa entrevistou alguns cafeicultores do interior paulista. As entrevistas com esses atores, ou com seus descendentes, têm sido amplamente utilizadas em trabalhos de cunho monográfico e memorialista, porém, ainda estamos engatinhando na sua utilização em trabalhos cujas preocupações são mais amplas. Como bem nos adverte Thompson ${ }^{9}$ e Ferreira \& Amado $^{10}$, o trabalho com a história oral exige cuidado e crítica, pois muitas vezes as informações colhidas revelam percepções de um determinado agente sobre um fato ou época que não automaticamente evidenciam representações fidedignas. No caso do passado como colono, as entrevistas tendem a demonstrar o esforço pessoal dos antepassados, dos "nonos e das nonas", ou a "bondade" ou "maldade" de determinado fazendeiro, de modo que se imputa obrigatoriamente ao pesquisador a missão de filtrar tais depoimentos, buscando dotá-los de sentido.

Fontes documentais tradicionalmente utilizadas e que são destaque no entendimento das relações de trabalho estabelecidas entre fazendeiros e trabaIhadores rurais são as chamadas cadernetas de colonos. Vinha impresso nessas brochuras um contrato-padrão, assinado pelas partes (conforme Lei do Patronato Agrícola de 1911), bem como o registro do "haver" e do "dever" dos trabaIhadores, a partir dos quais se percebia, ou não, a existência de saldos a favor do trabalhador. Trata-se de fonte com imensa importância para o entendimento da questão do trabalho na cafeicultura; contudo, carecemos de um maior número de registros, uma vez que se tratava de documentação privada que foi em grande parte extraviada ou deteriorada em função dos menores cuidados de preservação. A inexistência de um maior número de cadernetas disponíveis à consulta indica que provavelmente foram destruídas quando fazendeiros e/ou herdeiros decidiram jogar fora os "papéis velhos", lembrando que a maior parte desse tipo de registro ficava em poder do próprio trabalhador, pulverizando ainda mais a existência de tal documento histórico. Em alguns estudos dedicados à questão das relações de trabalho no campo, essa fonte fora largamente utilizada, tais como

6 BENINCASA, Vladimir. Velhas fazendas. Arquitetura e cotidiano nos Campos de Araraquara. 1830-1930. São Paulo: Edufscar; Imprensa Oficial, 2003.

7 FERRÃO, André Munhoz de Argollo. Arquitetura do café. Campinas; São Paulo: Editora da Unicamp; Imprensa Oficial do Estado de São Paulo, 2004.

8 SALLUM JR., Brasílio. Capitalismo e Cafeicultura. Oeste Paulista: 1888-1930. São Paulo: Duas Cidades, 1982.

9 THOMPSON, Paul R. A voz do passado:história oral. São Paulo: Paz e Terra, 1992.

10 FERREIRA, Marieta M. \& AMADO, Janaína. Usos e abusos da história oral. Rio de Janeiro: FGV, 1996. 
em Bassanezi ${ }^{11}$, Dean ${ }^{12}$ e em um texto por nós publicado em 2006, no qual utilizamos uma série composta por vinte cadernetas da Fazenda Pau d'Alho, situada em Campinas, entre 1927 e $1931 .{ }^{13}$ Raramente se encontram documentos dessa natureza que permitam a elaboração de uma série mais representativa, tratando-se de registros muito esparsos. Esperamos que isso possa ser superado no futuro, uma vez que as cadernetas constituem registros históricos magníficos, nos quais se percebem claramente as rendas monetárias e, em parte, as não monetárias auferidas pelos trabalhadores, bem como o peso com as despesas médicas, com as ferramentas, com a "Venda" (Armazém da fazenda) e principalmente com os onerosos adiantamentos (empréstimos) oferecidos aos trabalhadores.

Outra fonte que reúne potencialidades para o estudo da economia cafeeira são os inventários. Além de nos fornecer informações valiosas sobre patrimônio, dívidas ativas e passivas, posse de escravos e propriedades, os processos também revelam indiretamente alguns mecanismos de pagamento pelo trabaIho dos colonos na lavoura cafeeira. Em um dos inventários pesquisados em Faleiros ${ }^{14}$, percebe-se a existência de uma grande quantidade de "vales" emitidos pelo inventariado para o pagamento de seus colonos. Esses papéis foram emitidos com a finalidade de se reduzir os custos em mil-réis do processo de trabalho, sendo que seriam aceitos e liquidados na própria "venda" existente na fazenda, pertencente ao inventariado, ou, caso os colonos pudessem esperar, seriam ressarcidos dali a algum tempo, sacando o valor dos papéis que possuíam na fazenda. Evidentemente, o inventário em questão revela a criação de um sucedâneo monetário que duplamente beneficiava o fazendeiro, reduzindo-lhe as despesas em moeda corrente, ao mesmo tempo que impunha aos colonos a obrigatoriedade de liquidação dos seus saldos na própria fazenda, por suposto em termos de troca amplamente favoráveis ao fazendeiro. ${ }^{15}$ Esse exemplo elucida as potencialidades dessa fonte para a percepção dos mecanismos de exploração da mão de obra na economia cafeeira. De uma forma geral, a utilização de inventários tem sido reduzida nos estudos que versam sobre a questão do trabalho na cafeicultura.

Pesquisas desenvolvidas recentemente têm ampliado o universo documental disponível ao estudo da economia cafeeira, notadamente no que se refere às relações de trabalho vigentes entre fazendeiros e trabalhadores rurais. Visando compreender as relações estabelecidas nas lavouras de café de Franca entre 1880 e 1920, trabalhamos com duzentas e setenta e uma escrituras cartoriais que envolviam a formação e o trato de cafeeiros, buscando compreender os reflexos da expansão, da crise e da retomada da cafeicultura nas relações de trabalho estabelecidas. ${ }^{16}$ Em outro trabalho, que buscava entender o avanço da fronteira agrícola

11 BASSANEZI, Maria Silva C. Beozzo. Fazenda Santa Gertrudes, uma abordagem quantitativa das relações de trabalho em uma propriedade rural paulista, 1895-1930. Rio Claro: FFCL, 1973. Tese (Doutorado em Ciências Sociais).

12 DEAN, Warren. Rio Claro: um sistema brasileiro de grande lavoura 1820-1920. Rio de Janeiro: Paz \& Terra, 1977

13 FALEIROS, Rogério Naques. Os colonos do café e a crise de 1929: o "dever" e o "haver" nas cadernetas da fazenda Pau d’Alho de Campinas. In: I Seminário de História do Café: História e Cultura Material. Itu: Museu Paulista, 2006. Disponível em: www.mp.usp.br/cafe/textos.

14 FALEIROS, Rogério Naques. Homens do café: Franca 1880-1920. Campinas: IE/Unicamp, 2002. Dissertação (Mestrado em História Econômica). FALEIROS, Rogério Naques. Homens do Café. Franca, 1880-1920. Ribeirão Preto: Holos; Fapesp, 2008.

15 Inventário de Maria Clara de Jesus. Caixa 202, n.110. Arquivo Histórico Municipal de Franca-SP.

16 FALEIROS, Loc. cit. 
ocorrido em São Paulo entre 1917 e 1937, trabalhamos com duas mil e quarenta e sete escrituras cartoriais registradas em quatorze municípios, sendo que todas elas envolviam a formação e o trato de cafeeiros. ${ }^{17}$

Essas escrituras forneceram importantes informações, tais como o nome das partes contratantes, a quantidade e o estado dos cafeeiros a serem formados ou cuidados, as formas de remuneração, o nome das fazendas, as cláusulas que regulavam as possibilidades de acesso dos trabalhadores ao cultivo de outras culturas, as multas rescisórias, os termos de garantia, os adiantamentos previstos e a duração dos contratos. Além disso, a consulta à documentação cartorial permitiu-nos perceber as regiões em expansão no intervalo de nossas preocupações, fornecendo grandes potencialidades no que se refere à observação do movimento da cafeicultura numa perspectiva dinâmica, ou seja, do ponto de vista da realização e do registro cotidiano dos negócios, no caso, a formação de novas lavouras de café. Como veremos adiante, a consulta a essa documentação revelou mecanismos de exploração dos colonos ainda pouco discutidos pela historiografia. Por outro lado, esse tipo de fonte apresenta uma limitação pelo fato de que as informações lá contidas são muito específicas e fragmentárias, sendo que, vistas isoladamente, podem não ser representativas de realidades mais amplas. Deriva dessa limitação a necessidade de se relacionar as fontes cartoriais com registros de outra natureza, tais como almanaques, jornais, boletins, estatísticas e relatos memorialistas.

\section{Algumas interpretações sobre as relações de trabalho na cafeicultura paulista: o colonato e a ascensão social}

A questão das relações de trabalho vigentes na cafeicultura paulista suscitou em diferentes épocas e contextos um grande número de interpretações complementares e/ou divergentes sobre a natureza e as especificidades do chamado colonato. ${ }^{18}$ Alguns autores destacaram a virtuosidade de tal sistema de trabalho apontando-o como o responsável pela ascensão social e pela melhoria de vida dos trabalhadores, que a partir dos recursos acumulados tornar-se-iam proprietários. Outra parte da bibliografia aponta para a precariedade das relações estabelecidas entre fazendeiros e trabalhadores rurais, genericamente chamados de colonos, mas que poderiam ser também empreiteiros formadores de cafezais ou mesmo parceiros, sugerindo-nos que as possibilidades de ascensão social eram mais remotas. Objetivamos, agora, apenas destacar as principais referências que constituíram o debate acerca das relações de trabalho travadas na cafeicultura paulista.

17 FALEIROS, Rogério Naques. Fronteiras do Café: fazendeiros e colonos no interior paulista (1917-1937). Bauru; São Paulo: Edusc; Fapesp, 2010, p. 21.

18 O contrato padrão previa um pacote salarial e outros incentivos. Três formas principais de remuneração eram especificadas: salário em dinheiro para o trato das plantações de café, para a colheita dos frutos e para o trabalho diário não especializado (diária). Além disso, o contrato fornecia moradia gratuita e usufruto da terra para culturas de subsistência. Todos os salários se estabeleciam numa base por unidade — uma quantia fixa de dinheiro por mil pés tratados, por unidade de volume colhido de café ou por dia trabalhado. Porém, existiam outras formas de contratação de mão de obra para as fazendas, tais como as empreitadas e parcerias, recorrentes nas escrituras pesquisadas, nas quais não necessariamente se efetivavam pagamentos em dinheiro. Podemos entender essas modalidades de arregimentação de mão de obra como variações do dito "contrato padrão". 
José de Souza Martins e Brasílio Sallum Júnior analisaram as relações de trabalho entre fazendeiros e colonos sob uma perspectiva mais teórica, buscando nos referenciais existentes, sobretudo no marxista, o entendimento das especificidades de tais relações. Ambos apontaram para uma complexa imbricação de características capitalistas e "não capitalistas" no colonato. Sallum Júnior ${ }^{19}$, apoiando-se numa exegese da análise da renda em Marx, Livro III do Capital, afirma que os fazendeiros no oeste paulista seriam, ao mesmo tempo, proprietários territoriais e capitalistas. Sob a primeira face formariam os cafezais, arrendando terra aos formadores, e, sob a segunda, agiriam como capitalistas, pagando salários: a diferença entre o que o "colono" receberia e o valor de seu trabalho seria a renda paga, melhor dizendo, o preço pago pela utilização da terra. Assim, os colonos e os fazendeiros se vinculariam em dupla relação: uma capitalista (salário) e outra pré-capitalista (renda). Os fazendeiros seriam ao mesmo tempo proprietários rurais e produtores capitalistas. Os colonos, por sua vez, seriam assalariados e arrendatários em regime de subsistência. Para os fazendeiros, a renda corresponderia ao que eles deveriam ter pago em salários reais adicionais para manter a força de trabalho. Isto é, a renda poderia ser vista como salário de mercado para todo o trabalho já prestado, subtraindo-se o salário monetário já saldado. Do ponto de vista do "colono", essa "dupla" vinculação como arrendatário e assalariado corresponderia às suas expectativas, pois o acesso a terra era indispensável para a sobrevivência da família, no mais das vezes sendo até mais importante do que os próprios pagamentos efetivados em moeda. Adiante voltaremos a essa questão.

Importante assinalar, a partir de Sallum Júnior, que o colonato constituía relação de trabalho extremamente complexa, e que, a partir do acesso a terra fornecido ao "colono", confluir-se-iam os interesses de proprietários capitalistas e de arrendatários assalariados. Tal confluência de interesses era mais latente nas fazendas onde existia uma maior disponibilidade de terras para o cultivo intercafeeiro, melhor dizendo, naquelas fazendas situadas nas regiões de fronteira agrícola onde as lavouras estavam em formação, com maiores possibilidades de plantio de culturas de alimentos entre as fileiras do café. Para o "colono", isso significaria trabalhar em uma terra de melhor qualidade (virgem) e a possibilidade de reduzir o tempo de trabalho necessário para a manutenção do cultivo conjugado de diferentes culturas. Nas fazendas ainda robustas das zonas mais antigas, mas com pouca disponibilidade de terras para a formação de novos cafeeiros, restaria ao "colono" o cultivo de alimentos nas chamadas "terras baixas", terrenos extras, fora do cafezal, destinados a esse tipo de lavoura. Muitas vezes já esgotadas e com baixa produtividade, essas terras apresentavam, também, a desvantagem de demandar um maior tempo de trabalho. "Como resultado deste processo as fazendas mais antigas constantemente se viam ameaçadas de despovoamento"20, obstaculizando-se, pela não formação de novos cafeeiros, a dupla ligação que envolvia fazendeiros e colonos nas regiões de cafeicultura mais remota.

Em O Cativeiro da Terra, Souza Martins afirma que as relações de colonato caracterizavam-se como "não capitalistas", pois existiam vínculos monetários, não monetários e gratuitos, não se esquecendo, também, do caráter familiar do trabaIho, que não nos permite definir o colonato como uma relação capitalista de produção. Entretanto, essas relações seriam produzidas e organizadas, segundo o autor,

19 SALLUM JR., op. cit., p. 26.

20 SALLUM JR., op. cit., p. 188. 
a partir dos interesses da produção capitalista, melhor dizendo, da acumulação mercantil. Tem-se, então, a "produção capitalista de relações não capitalistas de produção". Para o autor, a hipótese é que o capitalismo, na sua expansão, não só redefine antigas relações, subordinando-as à reprodução do capital, mas também engendra relações não capitalistas igual e contraditoriamente necessárias a essa reprodução. ${ }^{21}$ Assim, a permanência de algumas características arcaicas da sociedade brasileira não poderia ser entendida meramente como um anacronismo incompatível com o desenvolvimento do capital, mas, pelo contrário, essas permanências revelavam características específicas de um desenvolvimento capitalista tardio, sem as quais a reprodução capitalista entraria em colapso.

Souza Martins também discute as condições dos colonos em outro plano de abstração, concluindo que as possibilidades de ascensão seriam muito reduzidas naquela situação. Existia, segundo o autor, um endividamento inicial (oriundo das despesas com a passagem transatlântica), e também dívidas contraídas ao longo do contrato de trabalho em função das próprias contingências das lavouras, das despesas alimentares e de saúde, da compra de ferramentas etc. Aliando-se a essas dívidas, existiriam, ainda, os mecanismos de monopolização do potencial de compra dos colonos, as chamadas economias de "caderneta", nos quais, com o estabelecimento de "Vendas" nas colônias, os fazendeiros agiriam em condições muito favoráveis, pois forneceriam crédito, manipulariam os valores e a esdrúxulos preços abocanhariam o excedente da produção de alimentos dos trabalhadores. Tal mecanismo seria coordenado por uma relação extremamente desigual, que, em conjunto com outras práticas, redundaria num alto grau de exploração da força de trabalho.

Para este autor, o acesso a terra fornecido aos colonos construía a ilusão de que eles trabalhariam para si, quando, na verdade, apenas garantiriam a sua mera reprodução como trabalhador, sem contar o fato de que os fazendeiros selecionavam para si os lotes de melhor qualidade. De acordo como autor, o colonato pressupunha a desigualdade entre as partes contratantes, o cativeiro da terra, sendo a propriedade fundiária fundamental para o estabelecimento da desigualdade vigente entre o fazendeiro e o "colono". Os rendimentos monetários dos trabalhadores derivariam do trato por mil pés de café e das colheitas, constituindo-se esse ganho, ainda com Souza Martins, uma parcela menos significativa de sua remuneração. Já com o trabalho nas fileiras intercafeeiras ou em terrenos extras, os colonos garantiriam o grosso da alimentação e a reprodução da família. Percebe-se, então, um mecanismo no qual o salário não seria a forma dominante da relação estabelecida, o que impedia que fazendeiros e colonos vivessem integralmente as ficções da igualdade engendrada pela troca aparentemente igual de tempo de trabalho por dinheiro. Assim, “do ponto de vista do 'colono', o trabalho necessário apareceria como trabalho sobrante e o trabalho sobrante, para o fazendeiro, era o que se revestia da aparência de trabalho necessário". ${ }^{22}$ Em outros termos, a plantação de alimentos, que era essencial aos colonos, cristalizava-se como secundária ao fazendeiro, e o que era essencial ao fazendeiro, a formação e/ou o trato do café, seria secundário para os colonos, entendido como um trabalho de menor importância. Ocorre que tal complexidade construía-se a partir da concentração fundiária e do monopólio da terra, e, jogando com isso, os fazendeiros estabeleceram

21 MARTINS, José de Souza. O Cativeiro da Terra. São Paulo: Livraria e Editora Ciências Humanas, 1979, p. 20. 22 MARTINS, op. cit., p. 88. 
uma forma de exploração do trabalho muito específica, na qual colonos possuíam a ilusão de que entregavam ao fazendeiro em forma de café o pagamento para trabalhar para si próprio, pensando-se assim "senhores" do seu trabalho nas lavouras de subsistência, quando estavam, na verdade, a meio caminho da transparência da exploração pela coerção e a meio caminho da "igualdade" pressuposta pelo trabalho livre.

Chiara Vangelista ${ }^{23}$ destaca a necessidade de se discriminar as ofertas e as demandas por trabalho na economia paulista da República Velha. Segundo a autora, as etapas do processo de produção de café exigiam diferentes perfis e impunham diversas demandas à sociedade: eram necessários homens desenraizados e aventureiros para os esporádicos trabalhos de derrubada das matas, famílias para a formação e para o trato dos cafezais, trabalhadores avulsos e eventuais para a colheita, assalariados para a manutenção de máquinas de beneficiamento e das instalações, para a construção de armazéns, tulhas e terreiros para a secagem dos grãos, entre tantas outras atividades, de modo que não podemos identificar no cenário rural paulista mecanismos e experiências de vida homogêneas numa realidade marcada por ofertas e demandas de trabalhadores tão singulares. Dada a complexidade do trabalho nas fazendas de café, a autora relativiza as discussões sobre as possibilidades de ascensão social, mostrando-nos a dificuldade de se discutir a questão frente aos inúmeros trabalhos, perfis e atores existentes na economia paulista do período.

Verena Stolcke ${ }^{24}$, tratando mais especificamente das "Colônias", destaca o fato de que os proprietários de fazendas possuíam um especial interesse em empregar núcleos familiares nas fazendas. Existia, para a autora, uma ideologia de solidariedade e cooperação familiar que permitia aos cafeicultores explorar ao máximo toda a família imigrante. A partir da preeminência da autoridade do marido/ pai sobre os membros da família, o trabalho seria todo organizado sobre a base familiar, e as remunerações, em nenhum momento, eram estabelecidas individualmente, sendo o grupo familiar coletivamente explorado.

A questão da fronteira agrícola merece destaque central nas interpretações que postulam condições positivas à ascensão social a partir das relações de colonato. Entre essas interpretações, merecem destaque Thomas Holloway ${ }^{25}$ e Maurício Font ${ }^{26}$. Para Holloway, a fronteira agrícola em constante expansão, característica própria de economias agroexpotadoras, criava uma instabilidade muito grande nas relações de trabalho estabelecidas entre fazendeiros e imigrantes nas zonas mais antigas. Verificava-se um intenso deslocamento de famílias de colonos para as regiões mais novas, virgens em produtividade tanto para o café, planta de caráter perene, quanto para as lavouras de alimentos. Outro fator a se considerar, também, era a disponibilidade de terras nas novas regiões, a partir da qual os colonos poderiam ter acesso a maiores terrenos, o que corresponderia a uma vantagem em relação às regiões mais antigas e de solos já desgastados e ocupados pelo café.

23 VANGELISTA, op. cit.

24 STOLCKE, Verena. Cafeicultura. Homens, mulheres e capital. (1850-1980). Trad. Denise Bottmann e João R. Martins Filho. São Paulo: Brasiliense, 1986.

25 HOLLOWAY, Thomas H. Imigrantes para o café: café e sociedade em São Paulo 1886.1934. Rio de Janeiro: Paz \& Terra, 1984.

26 FONT, Maurício. "Padrões de ação coletiva dos plantadores paulistas de café: 1932-1933." In: SORJ, Bernardo; CARDOSO, Fernando Henrique; FONT, Maurício (orgs.). Economia e movimentos sociais na América Latina. São Paulo: Brasiliense, 1985. 
Com base nesse mecanismo, as fronteiras criariam um efeito de atração quase irresistível, o que redundaria, também nas zonas antigas, em melhorias nas condições de ascensão dos colonos.

Maurício Font parece distinguir, também a partir das possibilidades criadas pela expansão das fronteiras em São Paulo, uma forma de colonização específica, distinta. Segundo o autor, existem bases suficientes para argumentar que as fases posteriores da expansão do café em São Paulo, notadamente nas décadas de 1920, 1930 e 1940, presenciaram o surgimento de outras formas de produção, principalmente de pequenos e médios proprietários. Esse argumento é sustentado pelos dados fornecidos por Sérgio Milliet (1939) e José Francisco de Camargo (1952), que apontam a existência crescente de pequenas e médias propriedades em São Paulo neste período, sobretudo nas regiões de recente desbravamento. A hipótese central desenvolvida pelo autor é a de que as combinações próprias das relações de colonato permitiram que alguns trabalhadores rurais se transformassem em produtores independentes de mercadorias, provendo, assim, as bases que tornaram possível a mudança para a produção cafeeira independente. Além de garantir sua subsistência, o direito de usufruto da terra permitiu a produção de excedentes alimentícios que, naquele contexto de expansão da urbanização da economia paulista, se tornaria, cada vez mais, uma das fontes básicas de receita monetária.

As conclusões de Font apontam para a existência de uma estrutura de oportunidades fluidas em São Paulo, que permitiria aos trabalhadores buscar as meIhores oportunidades dentro ou fora do sistema da fazenda. A dramática expansão na demanda de culturas alimentares, em virtude da urbanização, possibilitou às famílias com suficiente força de trabalho atingir economias consideráveis, ao destinar o usufruto dos lotes à produção de culturas comercializáveis. Para o autor, a economia mais ampla, nascida do setor de exportação do café, desenvolveu uma dinâmica própria que sustentou o surgimento de acordos alternativos de utilização e posse da terra, principalmente no contexto da fronteira em expansão. “Lá, os pequenos proprietários, prosperando na produção de diversos gêneros agrícolas, tornaram-se um elemento predominante na organização social. Esses processos minaram o íntimo monopólio da terra e do trabalho tradicionalmente reivindicado pelos fazendeiros." 27

\section{O que nos dizem os contratos de trabalho?}

Trazendo novas fontes para o debate, consultamos duas mil e quarenta e sete escrituras de formação e/ou trato de café, lavradas nos Livros de Notas dos Cartórios dos municípios de Campinas, Rio Claro, Ribeirão Preto, Franca, São Carlos, Araraquara, Botucatu, São Manuel, Jaú, Novo Horizonte, São José do Rio Preto, Catanduva, Lins e Pirajuí (ver mapas ao final do texto), entre 1917 e 1937, período no qual - em função da intervenção governamental no mercado cafeeiro (as defesas do café) e da existência de uma legislação altamente vulnerável no que se referia à apropriação de terras em grande escala nas zonas novas (Araraquarense, Noroeste e Alta Sorocabana) - , verifica-se um rápido processo de expansão da fronteira agrícola no estado de São Paulo, Brasil. Como esses livros constituíam a

27 FONT, op. cit., 1985, p. 242. 
única forma de registro público existente à época, lá se encontravam escrituras dos mais variados tipos: compra e venda de imóveis urbanos e rurais; e escravos em época mais remota; doações; cessão de crédito (destacadamente hipotecário); escrituras de compra e venda de café; empreitadas de construção de prédios e casas na cidade; atas de eleições; testamentos; adoção de menores; liquidação de débitos; reconhecimento de dívidas; e contratos de formação de sociedades agrícolas ou industriais etc. As escrituras de formação e trato de café, para as quais dedicamos maior atenção, forneceram importantes informações para nossa pesquisa, tais como o nome das partes contratantes, a quantidade e o estado dos cafeeiros a serem formados ou cuidados, formas de remuneração, o nome das fazendas, as cláusulas que regulavam as possibilidades de acesso dos trabalhadores ao cultivo de outras culturas, as multas rescisórias, os termos de garantia, adiantamentos e duração dos contratos.

Fazendeiros e trabalhadores lavravam escrituras por uma série de fatores: a) desconhecimento ou desconfiança entre as partes; b) tentativa de "segurar" a mão de obra na propriedade, mediante registro de multas, cauções e garantias em contrato; c) necessidade de uma melhor definição dos termos de contrato, tais como o plantio intercafeeiro; d) definição, a priori, das cláusulas que determinariam o estabelecimento da cobrança de taxas pelo transporte e beneficiamento da produção dos trabalhadores; e) pré-fixação de salários num contexto de crescente demanda por trabalho; f) garantia ao proprietário do direito de fiscalização das tarefas. Cabe salientar que os contratos tornavam-se instrumentos de opressão dos trabalhadores, visando minimizar as possibilidades de abandono da lavoura e garantir ao fazendeiro uma série de direitos unilaterais, como veremos adiante.

Eram dois os tipos de escrituras predominantes entre fazendeiros e trabalhadores: as empreitadas e as parcerias. Basicamente, a diferença entre essas escrituras era a forma de pagamento. Nas escrituras de parceria agrícola, geralmente, os trabalhadores receberiam como remuneração pelo trato ${ }^{28}$ a metade da produção dos cafeeiros contratados. Em grande medida, nesses casos, as escrituras versavam sobre cafeeiros já formados ou com formação quase concluída, sendo, portanto, predominantes nas regiões de cafeicultura mais antiga. Terminada a coIheita, a secagem e o beneficiamento, as sacas seriam divididas em função da proporção estabelecida, sendo essa a única fonte de renda do "parceiro".

Nas empreitadas, os trabalhadores seriam contratados para formar um determinado número de cafeeiros, recebendo como pagamento a totalidade da produção das árvores contratadas, ou, em alguns casos, além disso, receberiam uma determinada quantia por cada cova formada. ${ }^{29}$ Há que se considerar que os cafeeiros começariam a produzir algum fruto somente após o terceiro ou quarto ano e, mesmo assim, essa primeira colheita renderia uma produção diminuta, sendo que uma "produtividade adulta", digamos assim, só seria alcançada no sexto ou no sétimo ano de idade da planta. Justamente por isso os fazendeiros abriam mão dessa produção inicial e, após o vencimento do contrato, depois de quatro anos, deteriam cafeeiros com o ápice da produtividade ou algo muito próximo disso.

28 Entendia-se por trato, as atividades de carpa, combate aos brotos, adubação, cuidados com doenças, espalhamento do cisco, colheita, secagem, e, em alguns casos, beneficiamento dos grãos.

29 Uma cova abrigava de duas a cinco mudas. Sobre as que não "vingavam" era cobrada uma multa, e sobre as que pouco se desenvolviam, estabelecia-se uma proporção: "cova de dois anos", "cova de três anos", para as quais se pagava metade ou três quartos do valor combinado, respectivamente. 
Esse tipo de contrato foi predominante nas novas zonas de expansão da cafeicultura paulista entre 1917 e 1937.

A documentação consultada corrobora o que já foi escrito sobre o tema? Sim, de uma forma geral. As escrituras cartoriais pesquisadas fortalecem a consensual tese de que as melhores condições de remuneração pelo trabalho se concentravam nas regiões de avanço da fronteira agrícola. Porém, as escrituras cartoriais também revelam algumas informações novas acerca dessa questão. Autores aqui já citados, como T. Holloway, Brasílio Sallum Júnior e Chiara Vangelista, argumentam que o trabalho nas lavouras novas permitia ao "colono" maior renda em função da maior disponibilidade de terras para o plantio das chamadas culturas intercalares (milho, feijão e arroz) plantadas entre as "ruas" do café..$^{0}$ Isso decorria da pouca idade dos cafeeiros em formação nas zonas de fronteira, o que possibilitava o plantio de uma maior quantidade destas outras culturas, diferentemente do que ocorria em regiões de cafeicultura madura, onde os espaços eram diminutos. Justamente por isso os trabalhadores do café preferiam as fazendas situadas nas zonas de expansão, pois, comercializando os excedentes, poderiam auferir rendas monetárias e não monetárias. Segundo a bibliografia, as cláusulas contratuais que versavam sobre o plantio intercalar eram até mais importantes para os trabalhadores do que as que regulavam a remuneração em dinheiro, uma vez que lhes permitia o acúmulo de algum pecúlio. Nas palavras destes autores:

Para a grande lavoura, o novo regime significava o aproveitamento da carestia de gêneros e a demanda dos mercados urbanos para remunerar em parte a força de trabalho empregada nos cafezais. Por aí se compensava o baixo custo do salário agrícola. Em outros termos, a fazenda efetivava-se como empresa produtora de café exclusivamente (os alimentos eram produção do colono), reduzia os dispêndios com a mão-de-obra, aumentando os seus lucros, e transferia para os consumidores de alimentos comercializados, sobretudo os do meio urbano, uma parte do custeio do cafezal. ${ }^{31}$

Além do ganho direto do colono, a que estamos fazendo referência, ele aufere indiretamente vantagens de outra ordem e de maior valor. São as que resultam da cultura de cereais, feijão etc. Entre as filas de cafeeiros, e cujas colheitas lhes pertencem integralmente. ${ }^{32}$

Em muitos casos, os cereais e animais excedentes que o colono vendia proporcionavam uma importante fonte adicional de dinheiro. Tal renda extra podia ser adicionada às economias ou usada para comprar os itens não produzidos na fazenda, tal como farinha de trigo, açúcar, querosene, roupas e ferramentas. Como exemplo da importância que os próprios trabalhadores atribuíam às porções não monetárias do contrato de trabalho, um Vice-Cônsul italiano em Ribeirão Preto constatava, em 1903, que os colonos preferiam uma fazenda onde os salários em dinheiro eram pequenos, mas onde os privilégios de lavoura de alimentos e criação de animais eram generosos, a uma fazenda onde os salários eram melhores, mas sendo restritos os privilégios não monetários. Um observador francês anotava em 1909: "o que realmente permite que os colonos acertem o deve e o haver são as plantações que eles tem o direito de fazer por sua própria conta... Eles muitas vezes se preocupam mais com as cláusulas do contrato relacionadas com essas plantações do que com aquelas que determinam seus salários em dinheiro.”33

30 Os cafeeiros são geralmente plantados em fileiras, de modo que entre elas existe um espaço de aproximadamente três metros e meio, no qual se plantavam outras culturas.

31 VANGELISTA, op. cit., p. 198-199. (grifos nossos)

32 SALLUM JR., op. cit., p. 184. (grifos nossos)

33 HOLLOWAY, op. cit., p. 122. (grifos nossos) 
Abaixo, elaboramos uma tabela, comparando as condições de plantio dessas culturas em contratos lavrados em três municípios: Campinas (situado numa região de cafeicultura decadente - Central), Franca (região intermediária - Mogiana) e Catanduva (município situado na região Araraquarense, fronteira de expansão da cafeicultura paulista nas décadas de 1910 e 1920):

Tabela 1 - Plantio Intercafeeiro em Campinas, Franca e Catanduva.

\begin{tabular}{|c|c|c|c|}
\hline Contrato & Campinas (1923) & Franca (1920) & Catanduva (1918) \\
\hline 10 Ano & $\begin{array}{l}\text { Uma carreira de milho nas } \\
\text { replantas de até dois anos, } \\
\text { três carreiras de feijão entre } \\
\text { as ruas do cafezal formado e } \\
\text { duas carreiras de milho em } \\
\text { cada rua do cafezal novo; }\end{array}$ & $\begin{array}{l}\text { Plantio picado (sem } \\
\text { alinhamento) de feijão, } \\
\text { arroz, milho, batata e } \\
\text { fumo em cada rua do } \\
\text { cafezal; pasto de cinco } \\
\text { alqueires. }\end{array}$ & $\begin{array}{l}\text { Duas carreiras de } \\
\text { milho, quatro de feijão } \\
\text { ou quatro carreiras de } \\
\text { arroz em cada rua do } \\
\text { cafezal; pasto para } \\
\text { animais. }\end{array}$ \\
\hline 2o Ano & $\begin{array}{l}\text { Uma carreira de milho nas } \\
\text { replantas de até dois anos, } \\
\text { três carreiras de feijão entre } \\
\text { as ruas do cafezal formado e } \\
\text { duas carreiras de milho em } \\
\text { cada rua do cafezal novo; }\end{array}$ & $\begin{array}{l}\text { Duas carreiras de milho, } \\
\text { quatro de feijão e arroz e } \\
\text { uma de fumo e batatinha } \\
\text { em cada rua do cafezal; } \\
\text { pasto de cinco alqueires. }\end{array}$ & $\begin{array}{l}\text { Duas carreiras de } \\
\text { milho, quatro de feijão } \\
\text { ou quatro carreiras de } \\
\text { arroz em cada rua do } \\
\text { cafezal; pasto para } \\
\text { animais. }\end{array}$ \\
\hline 3o Ano & $\begin{array}{l}\text { Uma carreira de milho nas } \\
\text { replantas de até dois anos, } \\
\text { três carreiras de feijão entre } \\
\text { as ruas do cafezal formado e } \\
\text { duas carreiras de milho em } \\
\text { cada rua do cafezal novo; }\end{array}$ & $\begin{array}{l}\text { Duas carreiras de milho, } \\
\text { quatro de feijão e arroz e } \\
\text { uma de fumo e batatinha } \\
\text { em cada rua do cafezal; } \\
\text { pasto de cinco alqueires. }\end{array}$ & $\begin{array}{l}\text { Uma carreira de milho, } \\
\text { duas de feijão ou duas } \\
\text { carreiras de arroz em } \\
\text { cada rua do cafezal; } \\
\text { pasto para animais. }\end{array}$ \\
\hline 40 Ano & $\begin{array}{l}\text { Uma carreira de milho e } \\
\text { uma de feijão em cada rua } \\
\text { do cafezal (novo ou velho); }\end{array}$ & $\begin{array}{l}\text { Quatro carreiras de } \\
\text { arroz, quatro de feijão } \\
\text { ou uma de milho em } \\
\text { cada rua do cafezal; } \\
\text { pasto de cinco alqueires. }\end{array}$ & $\begin{array}{l}\text { Uma carreira de milho, } \\
\text { duas de feijão ou duas } \\
\text { carreiras de arroz em } \\
\text { cada rua do cafezal; } \\
\text { pasto para animais. }\end{array}$ \\
\hline 5o Ano & $\begin{array}{l}\text { Uma carreira de milho e } \\
\text { uma de feijão em cada rua } \\
\text { do cafezal (novo ou velho); }\end{array}$ & $\begin{array}{l}\text { Quatro carreiras de } \\
\text { arroz, quatro de feijão } \\
\text { ou uma de milho em } \\
\text { cada rua do cafezal; } \\
\text { pasto de cinco alqueires. }\end{array}$ & $\begin{array}{l}\text { Um alqueire de terras } \\
\text { para cultura por cada } \\
10.000 \quad \text { cafeeiros } \\
\text { contratados. Pasto para } \\
\text { animais }\end{array}$ \\
\hline 60 Ano & $\begin{array}{l}\text { Uma carreira de milho e } \\
\text { uma de feijão em cada rua } \\
\text { do cafezal (novo ou velho). }\end{array}$ & $\begin{array}{l}\text { Quatro carreiras de } \\
\text { arroz, quatro de feijão } \\
\text { ou uma de milho em } \\
\text { cada rua do cafezal; } \\
\text { pasto de cinco alqueires. }\end{array}$ & $\begin{array}{l}\text { Um alqueire de terras } \\
\text { para cultura por cada } \\
10.000 \quad \text { cafeeiros } \\
\text { contratados. Pasto para } \\
\text { animais }\end{array}$ \\
\hline
\end{tabular}

Fonte: Livro de Notas n. 167, folha 32. 1. ${ }^{\circ}$ Ofício Civil de Campinas 05/10/1923 e Livro de Notas n. 97, folha 12. 2. Ofício Civil de Franca. 20/03/1920. Livro de Notas n. 4 (Vila Adolpho). Fls. 61. 2. Ofício Civil de Catanduva. 01/07/1918.

Percebe-se nesta tabela que no município de Catanduva encontravam-se as melhores condições para o plantio intercalar, sendo que, nos dois últimos anos de contrato, os trabalhadores disporiam de um alqueire $\left(24.200 \mathrm{~m}^{2}\right)$ para cada dez mil pés de café contratados, condição muito superior às oferecidas nos outros municípios considerados. Certamente o objetivo de fornecer um maior acesso a terra ao colono do café era a redução dos custos monetários de produção, aos quais os fazendeiros eram tão recalcitrantes, sendo a consequência disso um alto grau de "nomadismo" dos colonos do interior paulista rumo às regiões de fronteira, aspecto também apontado pela bibliografia. 
O que a pesquisa com as escrituras cartoriais nos permitiu observar é que as regiões de fronteira, na verdade, eram mais atraentes ao trabalhador do que se supunha, pois lá também se praticava, mais comumente, remunerações em dinheiro pela formação de uma lavoura de café. A maior proporção de contratos envolvendo pagamentos em dinheiro foi encontrada nos municípios novos da região Noroeste: Pirajuí $(58,7 \%)$ e Lins (48,4\%). Em Ribeirão Preto, município da Mogiana, 62,1\% dos contratos lavrados envolviam pagamentos em dinheiro; contudo, a maioria dos contratos lá registrados versava sobre a formação de novas lavouras nas fronteiras. ${ }^{34}$ Assim, a documentação revela não existir uma proporção inversa entre salários e renda, sendo esses dois componentes superiores nas regiões novas. Cabe salientar que nas regiões mais antigas predominavam as parcerias, relação contratual na qual a produção de café seria dividida em duas partes e não se praticavam pagamentos monetários. Em Campinas, município de cafeicultura antiga na década de 1920, por exemplo, em apenas $10 \%$ dos contratos estavam previstos pagamentos em dinheiro. Ao todo, considerando as duas mil e quarenta e sete escrituras pesquisadas, 33,5\% previam salários monetários. Por conta dessas evidências, discordamos de Sallum Júnior, que traça uma relação inversamente proporcional entre renda e salários na cafeicultura, apontando que quando se aumentava a renda (acesso a terra), diminuía-se o salário por unidade de cafezal tratado e, num movimento contrário, quando a renda fosse menor, os salários seriam maiores. ${ }^{35}$

Existe por parte da bibliografia aparente subestimação da importância das cláusulas monetárias para as contas dos colonos, como depreendemos dos excertos acima destacados. Não estamos aqui negando a importância da produção de gêneros alimentícios para esses trabalhadores, apenas considerando que os pagamentos em dinheiro também poderiam ter um grande peso em suas contas, e que certamente contribuíam para o "nomadismo" da mão de obra anteriormente citado, uma vez que um maior número de contratos envolvendo pagamentos em dinheiro foi encontrado justamente nas regiões novas. Exemplificando, comparemos abaixo duas situações, a de Daniel Cruz, um empreiteiro em Pirajuí, que foi contratado por Jorge Elias para formar dez mil cafeeiros na fazenda São Sebastião, situada numa região de fronteira ${ }^{36}$, e a de Virgílio Dias Fernandes, parceiro em Franca arregimentado por Justiniano Alves Taveira para tratar de uma lavoura de mesma dimensão na Fazenda Aliança, situada numa região intermediária na década de $1920 .{ }^{37}$ Nesses dois casos, os trabalhadores foram submetidos a contratos com duração de quatro anos que expirariam em 1929. Nesse contrato de formação lavrado em Pirajuí, a remuneração do empreiteiro seria composta por toda a produção do quarto ano da lavoura e por uma determinada quantia paga por cada cova formada, no caso $1 \$ 000$ (valor que pouco variava de região para região). Já a remuneração do parceiro de Franca seria formada unicamente por metade da produção de café. Abaixo, para calcular os rendimentos desses trabalhadores, consideramos a produtividade anual dos cafeeiros de cada um desses municípios ${ }^{38}$ (em arrobas por mil pés), multiplicando-a pelo preço pago pela arroba ao produtor. Cabe salientar que utilizamos os preços praticados em Ribeirão Preto, importante

34 FALEIROS, op. cit., 2010, p. 135.

35 SALLUM JR., op. cit., p. 198.

36 Livro de Notas n. 25. fls. 83. 2. ${ }^{\circ}$ Ofício Civil de Pirajuí. 14/08/1926.

37 Livro de Notas n. 131, fls.71. 2. Ofício Civil de Franca. 28/08/1926.

38 Extraímos estas informações do Boletim O Café: Estatísticas de produção e de comércio. São Paulo: Secretaria da Agricultura, Comércio e Obras Públicas, 1909-1938. 
centro comercial onde pesquisamos escrituras de compra e venda de café e elaboramos uma série de preços. ${ }^{39}$ As remunerações seriam as seguintes:

Tabela 2 - Remuneração de Trabalhadores em Campinas e Pirajuí 1926-29.

\begin{tabular}{|c|c|c|c|c|c|}
\hline \multicolumn{6}{|c|}{ Empreitada $1926-29-10.000$ cafeeiros } \\
\hline Ano & $\begin{array}{c}\text { Preço (@/1.000) } \\
\text { Rib.Preto. }\end{array}$ & $\begin{array}{c}\text { Produtividade } \\
\text { Franca }\end{array}$ & $\begin{array}{c}\text { Produtividade } \\
\text { Pirajuí }\end{array}$ & $\begin{array}{c}\text { Remuneração } \\
\text { Parceiro } \\
\text { Franca }\end{array}$ & $\begin{array}{c}\text { Remuneração } \\
\text { Empreiteiro } \\
\text { Pirajuí }\end{array}$ \\
\hline 1926 & $27 \$ 500$ & 46,1 & 63,5 & $6: 215 \$ 000$ & 0 \\
\hline 1927 & $23 \$ 800$ & 51,0 & 28,4 & $3: 962 \$ 700$ & 0 \\
\hline 1928 & $28 \$ 000$ & 52,9 & 99,7 & $6: 972 \$ 000$ & 0 \\
\hline \multirow[t]{2}{*}{1929} & $29 \$ 800$ & 26,8 & 29,8 & $3: 754 \$ 800$ & $8: 880 \$ 400$ \\
\hline & & & & 0 & 10:000\$000 \\
\hline Total & & & & $20: 904 \$ 500$ & $18: 880 \$ 400$ \\
\hline
\end{tabular}

Fonte: Faleiros, 2010.

Evidentemente, tanto parceiros quanto empreiteiros estavam sujeitos à variação nos preços e de produtividade, de modo que as possibilidades de ganho se alteravam muito de ano para ano. Na situação considerada acima, o parceiro de Franca receberia cerca de vinte e um contos de réis ao final dos quatro anos de contrato, somando-se o valor pago pela metade da produção anual de dez mil cafeeiros entre 1926 e 1929. Já o empreiteiro de Pirajuí receberia cerca de nove contos de réis pela totalidade da produção de café do quarto ano e dez contos por cada cova formada, totalizando cerca de dezenove contos. Ou seja, nessa situação, o que permitiria que o empreiteiro situado na fronteira tivesse uma remuneração próxima a de um parceiro sediado numa região já "madura" seria o pagamento em dinheiro, e parece-nos um exagero afirmar que os colonos pouca atenção davam a essas cláusulas, privilegiando unicamente o acesso à produção intercalar, conforme destacou Holloway no excerto anteriormente citado. Evidentemente, como já observamos, os colonos arranchados nas fronteiras teriam maiores possibilidades para o plantio das culturas intercalares, tornando esses contratos mais atraentes também sob esse aspecto. Esses exemplos contrariam a inversa relação entre renda e salário constatada por Sallum Júnior, pois justamente nas regiões de fronteira, onde era possível se auferir uma renda maior, plantando-se maior quantidade de gêneros alimentícios, era mais recorrente o pagamento por cova formada. A própria inflexibilidade do salário agrícola contraria tal tese, pois, ao observarmos contratos lavrados em diferentes regiões, tanto novas quanto antigas, percebe-se que o valor pago por cada cova formada não se altera substancialmente. ${ }^{40}$

Ponto comum na bibliografia sobre o tema das relações de trabalho na cafeicultura aqui considerado é o fato de que, para esses autores, os colonos, empreiteiros e parceiros possuiriam liberdade para negociar suas produções de café e de gêneros alimentícios. Os trechos em negrito dos excertos evidenciam isso, indicando que os colonos teriam total controle sobre os alimentos que produziam, ou mesmo sobre a quantidade de café que lhes pertenceria. Mais do que isso, as produções de arroz, milho, feijão e demais culturas seriam mecanismos centrais no processo de produção de café, pois permitiam a redução dos custos monetários de produção, ampliando a possibilidade de elevados lucros para os fazendeiros. Tanto os autores de marcada veia marxista (Martins e Sallum Júnior) quanto os

39 FALEIROS, op. cit., 2010, p. 104.

40 FALEIROS, op. cit., 2010, p. 450. 
demais (Holloway, Font, Vangelista, Stolcke) destacaram em seus estudos essa "funcionalidade" das culturas de alimentos, alguns dos quais apontaram que a comercialização dos excedentes fora o que permitiu a muitas das famílias sediadas nas fazendas a constituição de poupanças posteriormente invertidas na compra de algum lote de terras. ${ }^{41}$

Evidentemente, é ponto pacífico o fato de que as chamadas produções intercalares desempenhavam importante função na subsistência dos trabalhadores e consequentemente dos salários em dinheiro; porém, consideramos aqui que a bibliografia sobre o tema desconsiderou outro aspecto dessas produções: a sua viabilidade como atividade geradora de lucro para o fazendeiro, notadamente num momento de crescimento das cidades em São Paulo.

Tratemos agora da documentação consultada (Livros Cartoriais) para explicitar nossos argumentos, que indicam um grau de exploração da força de trabalho maior do que se supunha.

$\mathrm{Na}$ ampla maioria dos contratos pesquisados nos municípios citados, independentemente de se situarem em zonas novas ou antigas, os fazendeiros impunham cláusulas que Ihes garantiam a "preferência de venda" sobre as produções dos colonos, tanto de alimentos quanto de café. Nossa hipótese é a de que essa "negociação preferencial" era permeada por uma relação extremamente desigual travada entre contratantes e contratados, o que poderia significar uma redução dos preços dos produtos vendidos pelo trabalhador. Há que se questionar, nesse ponto, qual era a possibilidade de os colonos negociarem livremente os excedentes de sua produção. Existia um mercado para esses produtos? Quem eram os outros compradores? Os trabalhadores poderiam escolher livremente para quem vender? Tinham acesso direto aos consumidores urbanos? Acreditamos que não.

Pensamos que intermediações extremamente desfavoráveis aos trabalhadores eram operadas nessa relação contratual, principalmente quando os trabalhadores caíam nas "amarras" dos adiantamentos. Acreditamos que a concessão de adiantamentos aos colonos figurava como importante mecanismo de expropriação, diminuindo a futura capacidade de negociação do trabalhador no momento de liquidação do contrato e tolhendo seus direitos de dispor de suas produções como bem entendesse. Exemplificando, quando em 1929 o empreiteiro Otta Kiuziro contratou Yamamoto Keinzo, Imoto Zengoro, Tanaka Guiytero e Meda Gohe para formar trinta e seis mil cafeeiros numa fazenda localizada em Rancharia, durante quatro anos, estabeleceu-se a seguinte cláusula contratual: “os outorgados não poderão vender cereais colhidos na propriedade do outorgante, sem consentimento deste, estando devendo ao mesmo qualquer quantia". Esse caso evidencia a importância estratégica dos adiantamentos para se "amarrar" os trabalhadores em termos de negociação dos excedentes produzidos, e não apenas como um mecanismo para "fixar" o trabalhador na fazenda, como sempre fora destacado pela bibliografia.

Ainda tratando dos adiantamentos, em 1930, Luiz Bezerra de Castro contratou os irmãos José, Antônio e Miguel Marchetti para tratar de dezoito mil e novecentos cafeeiros em regime de empreitada no sítio Bairro Paraíso, em Igaraçu do Tietê. Fora aberto aos trabalhadores um crédito na mercearia de $300 \$ 000$ para que cobrissem as despesas iniciais do contrato, que correriam por sua conta. Ser-lhes-ia cobrada uma taxa de juros de $8 \%$ ao ano, de modo que junto com a empreitada

41 Ver a atuação de algumas Companhias de Colonização, tais como a CAIC, que facilitavam a aquisição de lotes, parcelando o pagamento pela propriedade. 
"correria" um contrato de empréstimo, que comprometeria parte da futura renda dos Marchetti, pois a dívida seria abatida da parcela da produção que lhes cabia. ${ }^{42}$ O mesmo expediente fora usado por Jacob Murbach, que ao fechar uma empreitada com Victorio Silvestrim para a formação de cinco mil e quinhentos cafeeiros no Sítio Palmeiras, em Botucatu, adiantou-lhe um conto de réis ${ }^{43}$, e também por Lauro Sodré Ribeiro, que ao acertar uma parceria sobre a produção de trinta e cinco mil pés de café e dez alqueires de cereais, com José Januário, na fazenda Santa Maria, em Bofete, forneceu-lhe 300\$000 a título de empréstimo..$^{44}$ Os empréstimos e adiantamentos eram amplamente recriminados pela Agência Oficial de Colocação, órgão criado para normatizar as relações de trabalho no campo ${ }^{45}$, pois estabeleciam dependências dos trabalhadores em relação aos fazendeiros, tornando-os assim mais suscetíveis a aceitarem termos de negociação não favoráveis, como, por exemplo, vender sua parcela da produção de café e cereais a preços abaixo do mercado, porém, nunca deixaram de ser praticados. Tais dependências se tornaram ainda mais explícitas quando percebemos que o fazendeiro constituía a única e exclusiva fonte de crédito, sendo que temos que considerar, também, que em muitos casos os empréstimos e adiantamentos não significavam que o trabalhador teria acesso ao "dinheiro vivo", mas disporia de um crédito aberto na mercearia da fazenda.

As mercearias, ou “vendas", por seu turno, também funcionavam como peça central na exploração dos trabalhadores, pois muitas vezes, em vez de receberem pagamentos em dinheiro, Ihes era aberto um crédito na venda, obrigando-os a ali queimar seus saldos, adquirindo produtos que não reuniam condições de produzir, mas que eram indispensáveis à vida rural naquele contexto, tais como sal, farinha de trigo, ferramentas, arames etc. Pode-se pensar que as vendas foram essenciais para a concentração da produção de gêneros alimentícios e de café nas mãos dos fazendeiros, pois lá se efetivavam relações comerciais amplamente favoráveis a estes. Há casos, como na região Mogiana, em que os fazendeiros criavam notas e moedas que circulavam na propriedade e circunvizinhanças, criando-se uma espécie de sucedâneo monetário com um raio de ação limitado, mas que cumpria importante missão de redução dos custos monetários de produção e impunham a obrigatoriedade de liquidação daquela "moeda" somente onde fosse aceita: na venda da fazenda. Outra forma de exploração comum a todas as regiões pesquisadas fora a utilização da estrutura da fazenda para reduzir a parcela de café ou de alimentos que caberia, segundo contrato, aos trabalhadores. ${ }^{46}$

Existiam também outras formas de coibir a livre negociação dos cereais por parte dos trabalhadores, cobrando-lhes uma determinada quantia pelo transporte das sacas, como se depreende do seguinte trecho: "os cereais que os empreiteiros colherem no sítio serão vendidos pelos mesmos, por intermédio da administração, que fará o transporte dos ditos cereais ao preço de $3 \$ 000$ por saco de $60 \mathrm{kg".} .47$ Evidentemente, a taxação sobre as quantidades transportadas praticamente proibia a comercialização com outros agentes, limitando o mercado para os parceiros e empreiteiros. Numa outra situação, num contrato lavrado entre Lauro Dias, de Bebedouro, e Venerando Casalindo e outros, para formar quarenta e três mil e quinhentos cafeeiros na fazenda Santa Maria, em Lins, os contratados se obrigavam a

42 Livro de Notas n. 105, fls. 188. 1. ${ }^{\circ}$ Ofício Civil de São Manuel. 19/11/1930.

43 Livro de Notas n. 123A, fls. 28. 1. ${ }^{\circ}$ Ofício Civil de Botucatu. 29/11/1928.

44 Livro de Notas n. 128A, fls. 150. 1. ${ }^{\circ}$ Ofício Civil de Botucatu. 22/12/1936.

45 FALEIROS, op. cit., 2006.

46 FALEIROS, op. cit., 2010, p. 159.

47 Livro de Notas n. 11, fls. 74. 1. ${ }^{\circ}$ Ofício Civil de Lins. 20/01/1930. 
"dar preferência ao contratante para a venda de cereais, exceção feita aos colhidos no primeiro ano, que deveriam Ihe ser vendidos com a diferença, para menos, de $2 \$ 000$ por saca, de acordo com os preços vigentes na ocasião"..$^{8}$ Essa cláusula contratual identifica nitidamente a possibilidade de o fazendeiro adquirir parte da produção dos colonos a preços menores do que os praticados no mercado.

Nesse mesmo sentido, atuou Pedro Altenfolden Cintra Silva, que em 1934 contratou Rosalino Bellini para tratar de trinta mil e oitocentos cafeeiros abandonados, em regime de parceria, na Fazenda Nossa Senhora da Solette, em São Carlos. Bellini receberia como remuneração dois terços da produção dessa lavoura, e também teria direito ao plantio intercafeeiro. ${ }^{49}$ Chama a atenção nesse caso o fato de Cintra Silva estabelecer em contrato a compra da produção do contratado a $\mathbf{8 0}$ \% do valor de mercado na ocasião da venda, revelando ser plausível a hipótese de os trabalhadores se submeterem às táticas de estreitamentos de mercado impostos pelos fazendeiros. Caso os trabalhadores estivessem endividados por conta dos adiantamentos e das compras realizadas nas "Vendas", esses estreitamentos poderiam ser ainda maiores, de modo que boa parte da produção que lhe cabia nem sequer chegava às suas mãos.

Outra forma de se extrair excedentes dos trabalhadores era obrigá-los a ceder gratuitamente parte da produção de alimentos. Na escritura lavrada entre Francisco Guzzo e Miguel Rubi (espanhol), “obrigava-se o outorgado a dar ao outorgante, por ano, das plantações que tiverem quatro sacos de milho debulhado, quatro sacos de feijão e dois sacos de arroz limpo". ${ }^{50}$ Pode parecer uma quantidade irrisória (quatro sacos anuais), porém, imagine as quantidades de alimentos acumulados pelo fazendeiro ao estabelecer esse tipo de expropriação com todos os trabalhadores da fazenda. Certamente o objetivo prioritário de tais cláusulas era minorar os gastos do fazendeiro com a compra desses alimentos nos mercados citadinos, tornando-se o casarão da fazenda praticamente uma unidade autossustentável, bem como o palacete ou a casa construída no espaço urbano. Pode-se pensar também que, de alguma forma, caso angariasse grandes quantidades de alimentos, o fazendeiro poderia organizar a colocação dessa produção no mercado, abastecendo as vendas rurais e as casas de comércio localizadas na cidade, auferindo lucros a partir de um circuito promissor, dado o avanço da urbanização. Essa espécie de "talha" praticada na cafeicultura fora recorrente em outras escrituras, variando-se as quantidades repassadas gratuitamente ao fazendeiro. Lázaro Carlos Gonçalves, por exemplo, ao contratar Constante Pope para "tocar" em parceria os cafeeiros da Fazenda São João da Boa Vida, em São Carlos, estendera a divisão igualitária da produção também para o arroz, o milho, o feijão e as demais culturas, beneficiando-se de culturas que eram reconhecidamente pertencentes aos trabalhadores, segundo o que indica a bibliografia..$^{11}$

Ainda tratando dessa questão, um indício interessante sobre a concentração da produção de alimentos nas mãos dos proprietários é a escritura lavrada em 1923 entre Antônio Petraglia e os trabalhadores Waldemar Berdini e Marcelino Miguel Berdini, em Franca. Nesse contrato, os Berdini se obrigavam a tratar de oito mil cafeeiros, já plantados na chácara Vila Euphrásia, recebendo $0 \$ 400$ por cada cova formada, além de toda a produção de café num prazo de quatro anos.

48 Livro de Notas n. 16, fls. 55. 2. ${ }^{\circ}$ Ofício de Pirajuí. 08/11/2006.

49 Livro de Notas n. 93. fls. 111. 2. Ofício Civil de São Carlos. 21/08/1934.

50 Livro de Notas n. 69. fls. 73. 2..$^{\circ}$ Ofício Civil de São Carlos. 03/08/1919.

51 Ver os trabalhos de Emília Viotti da Costa (1979), Thomas Holloway (1984), Maurício Font (1985) e Brasílio Sallum Jr. (1986). 
Possuíam também o direito de exercer o plantio intercafeeiro e direito a um pasto, mas obrigatoriamente teriam que ceder a Petraglia um carro de milho e um saco de feijão por ano, gratuitamente. ${ }^{52}$ David Bernardes e João Lombardo, por exemplo, teriam que ceder ao Capitão Manoel Alves Pereira metade da produção de bananas e laranjas..$^{53} \mathrm{Em}$ Jaú, algumas escrituras cartoriais também sugerem que se estabeleciam mecanismos de expropriação também sobre a produção de alimentos dos colonos, como no contrato lavrado em 1936, quando Arthur Lopes Nogueira contratou Francisco Royo e José Lobo para cuidar dos cafeeiros da fazenda Recreio, em Pederneiras. Tratava-se de uma parceria, na qual os contratados teriam direitos sobre $50 \%$ da produção de café e $80 \%$ da produção das demais lavouras, sendo o restante pertencente ao fazendeiro, indicando que a parceria se estenderia também às demais plantações. ${ }^{54}$

Os estreitamentos de mercado e as apropriações unilaterais de parte da produção dos trabalhadores evidenciados nos parágrafos anteriores ganham sentido quando pensamos que os fazendeiros se interpunham entre os seus colonos e o mercado consumidor. Evidentemente existia uma "hierarquia de rentabilidades", na qual a atividade voltada à exportação mostrava-se a mais lucrativa, porém a produção de alimentos voltada ao mercado interno também constituía uma atividade interessante aos fazendeiros. Contrariando a bibliografia, acreditamos que os cafeicultores também operavam nesse mercado, concentrando a pulverizada produção de seus subordinados e comercializando-as nas Casas Comerciais e Armazéns localizados nas cidades mais próximas, que, por seu turno, realizavam uma concentração ainda maior dessas produções e as remetiam, por ferrovia, aos principais centros consumidores de alimentos, Campinas e São Paulo. Acreditamos que os "estreitamentos de mercados" impostos aos trabalhadores rurais captados direta ou indiretamente nas escrituras pesquisadas indicam a existência de tal circuito, que reservava rentabilidade considerável aos agentes que nele atuavam. ${ }^{55}$

Tratando agora do café, outro mecanismo utilizado para se diminuir o número de sacas que pertenceriam aos trabalhadores era a cobrança de taxas em espécie pela utilização da máquina de beneficiamento. Em alguns casos, eram aplicadas multas, caso o colono beneficiasse seus cafés em máquinas de outras fazendas ou mesmo na cidade, como na escritura lavrada entre a Fazenda Reunidas Irmãos Camargo, sediada na capital do estado, e os empreiteiros Antônio Piccoli, João Pires, José Pardo, Raphael Carvalho, Felix Pardo, Antônio Domingues, Izaías Domingues, Rogério Moura, José Antônio Domingues, João Adobbo, Gabriel Moralez e João Mascarin, que durante seis anos teriam que formar setenta e nove mil cafeeiros na Fazenda Salto, em São Carlos. ${ }^{56}$ Os empreiteiros receberiam como remuneração toda a produção dessa lavoura, e também poderiam utilizar os pastos da fazenda para suas criações e para o plantio de cereais nas fileiras do café. Por outro lado, toda a produção dos colonos teria que ser obrigatoriamente beneficiada na Fazenda ao preço de $0 \$ 400$ por arroba. Considerando que a produtividade nesse município para o ano de 1918 era de quarenta e cinco arrobas por mil pés, estimamos que por esse mecanismo o fazendeiro embolsaria cerca de quatro contos e quinhentos mil réis entre 1922 e 1924, anos produtivos dos cafeeiros formados em 1918.57 Em muitos casos, estipulavam-se preços proibitivos à utilização de outras máquinas

52 Livro de Notas n.109, fls.80. 2..$^{\circ}$ Ofício Civil de Franca. 16/07/1923.

53 Livro de Notas n.145, fls.70. 2..$^{\circ}$ Ofício Civil de Franca. 05/05/1928.

54 Livro de Notas n.220, fls.31. 2. Ofício Civil de Jaú. 20/07/1936.

55 FALEIROS, op. cit., 2010, p. 468.

56 Livro de Notas n. 67. fls. $95.2 .^{\circ}$ Ofício Civil de São Carlos. 03/08/1918.

57 Consideramos a produtividade do ano agrícola de 1921-22, de quarenta e oito arrobas de café por cada mil pés. 
de beneficiamento que não as indicadas em contrato, como no caso de Galdino Rosa Lima que, ao contratar os espanhóis João Fernandes Fernandes e Manuel Bernabé Crisol, estipulou o preço de $\mathbf{1} \$ 000$ pelo beneficiamento de cada saco de $60 \mathrm{~kg}$, desde que fosse realizado na máquina de Luiz Chrisógono de Castro ${ }^{58}$, em Franca; caso o beneficiamento fosse feito em outra máquina, os trabalhadores teriam que pagar $\mathbf{2} \$ \mathbf{0 0 0}$ pela mesma operação. Inviabilizando o beneficiamento em outros equipamentos, os fazendeiros garantiam para si uma grande demanda que mantinha a viabilidade da estrutura montada na fazenda. Evidentemente, essas práticas indicam significativa redução da parcela de café que caberia aos trabalhadores, evidenciando que a modernização da infraestrutura das fazendas potencializava a exploração do trabalho, dando caráter permanente aos desnivelamentos sociais, sendo, por esse prisma, também decisivas para a acumulação de capitais no complexo cafeeiro. A cobrança de taxas para o transporte da produção dos trabalhadores dos seus respectivos talhões até as máquinas ou armazéns agia no mesmo sentido, valendo-se os proprietários das estradas, carroças, carros e animais existentes na fazenda. ${ }^{59}$

As despesas com transporte também atuavam como mecanismos que beneficiavam os fazendeiros em sua relação com os trabalhadores do café. Sebastião Botelho, em empreitada lavrada em 1935, acertou a formação de sessenta e três mil cafeeiros com José Bordim e outros na fazenda São João, localizada em Santa Cruz do Rio Pardo. Os empreiteiros receberiam $0 \$ 800$ por cada cova formada e toda a produção de café, além do direito de cultivar arroz, milho e feijão nas fileiras do cafezal. Por outro lado, teriam que pagar $\mathbf{2 \$ 0 0 0}$ por carreto entre a sua roça e o terreiro de secagem, além de uma taxa de $4 \$ 000$ sobre cada carro estranho à fazenda que adentrasse a porteira, inibindo a negociação da sua produção com outros compradores..$^{60}$ Essa evidência indica que os fazendeiros utilizavam a estrutura montada na fazenda para abocanhar uma parcela maior das produções dos trabalhadores, impondo o monopólio do transporte das sacas.

O mais cruel disso é que muitas vezes essa estrutura utilizada para expropriar ainda mais os trabalhadores era construída por eles próprios, como indica a escritura lavrada entre Paula Victória Barrancos e Euselino Soares Ribeiro. Nesse contrato de empreitada, lavrado em Novo Horizonte, Soares Ribeiro teria como remuneração toda a produção de café ao final de quatro anos, sendo que "o proprietário nada pagaria ao segundo contratante pela formação dos quatro mil pés de café, e demais benfeitorias que o mesmo tenha feito em sua propriedade". ${ }^{61}$ Por se tratar da formação de uma lavoura numa região de fronteira, é bem provável que na fazenda ainda não existissem casas para moradia, estradas, pastos cercados, chiqueiros para os porcos, pomares e hortas, de modo que para garantir a viabilidade de sua existência, o contratado teria que construir todas essas benfeitorias sem nada receber, como indica o excerto acima. A ideia é a de que não só os cafeeiros eram formados a baixíssimo custo, mas também uma significativa parte da estrutura de produção da fazenda, destacadamente aquelas obras diretamente ligadas ao rebaixamento dos custos monetários dos fazendeiros. ${ }^{62}$

Nesse sentido, podemos destacar as escrituras em que o ônus da construção de benfeitorias recaía sobre os trabalhadores. Em 1928, Deocleciano Rodrigues

58 Livro de Notas n.124, fls. 68. 2. ${ }^{\circ}$ Ofício Civil de Franca. 01/10/1925.

59 FALEIROS, op. cit., 2010, p. 475.

60 Livro de Notas n. 215, fls. 21. 2. ${ }^{\circ}$ Ofício Civil de Jaú. 27/07/1935.

61 Livro de Notas n. 13, fls. 92. 2..$^{\circ}$ Ofício Civil de Novo Horizonte. 04/03/1926.

62 FALEIROS, op. cit., p. 365. 
Seixas contratou Faustino Martins para formar vinte e cinco mil cafeeiros na Fazenda Boa Vista, em Araraquara, durante quatro anos. Receberia como remuneração $1 \$ 000$ por cada cova formada ao final do período, além de toda a produção de café. Contudo, caso fizesse alguma benfeitoria na propriedade, não seria ressarcido, mesmo que essas construções fossem fundamentais para o bom andamento da empreitada, tais como terreiros, tulhas, curvas de nível para as enxurradas etc. Definiu-se a seguinte cláusula entre as partes:

Quaisquer benfeitorias, pastos, estradas, ranchos, plantações, e tudo quanto mais o segundo contratante haver necessidade de fazer ou construir no imóvel, inclusive cercas, mangueirões, poços, etc., findo o presente contrato passarão a pertencer ao outorgante independente de qualquer pagamento ou indenização. ${ }^{63}$

Outro exemplo é o caso dos trabalhadores César e Vicente Paulino, que, quando contratados pelo Coronel Joaquim Pereira Goulart, em 1923, obrigaram-se contratualmente a construir as casas em que morariam e um pasto para quarenta animais. ${ }^{64}$ Além da construção da casa, os trabalhadores responsabilizavam-se pela construção de benfeitorias como o mangueirão para os porcos, pela construção de cercas e pela formação de pastos para o número de animais estipulados em contrato, pela construção de paiol, tulha e pela manutenção das estradas da fazenda. Por esses mecanismos, o fazendeiro equipava e desenvolvia a estrutura da fazenda sem custo algum, e nos contratos futuros poderia negociar em melhores condições, já que toda a estrutura de habitação dos trabalhadores já estaria montada.

Outra forma de exploração dos trabalhadores era a obrigatoriedade de exercer funções de manutenção da fazenda sem o recebimento de nenhuma remuneração. Essa espécie de "corvéia" se referia às funções de manutenção e formação de pastos, conserto de cercas, abertura de estradas e construção e, em alguns casos, o trabalho na própria colheita, caso fosse necessária uma mão de obra suplementar. Emílio Martins, ao contratar Flauzino Marques e João Link para a formação de cinco mil cafeeiros na Fazenda Santa Mariazinha, em São Carlos, definiu a seguinte cláusula na escritura: "o empreiteiro se obriga a trabalhar na fazenda dos proprietários no roçamento de pastos sem receber remuneração nenhuma". ${ }^{65}$ Nesse caso, trata-se dos serviços de manutenção dos pastos, mas poderia ser qualquer outro; o importante é que os trabalhadores cediam dias de trabalho gratuito aos fazendeiros, explicitando a relação desigual travada entre ambos.

Vigoravam nos contratos algumas cláusulas que tinham como objetivo segurar os trabalhadores nas fazendas. Os contratos eram tão "leoninos" que os fazendeiros reservavam-se o direito de não pagar, ou pagar quando lhes conviesse, como se depreende do seguinte trecho: "caso não possa o proprietário pagar o contratado no final desta empreitada, terá um ano de prazo para efetuar o pagamento" ${ }^{66}$, ou

se no vencimento deste contrato o primeiro outorgante não fizer o pagamento ao segundo da importância verificada de acordo com as cláusulas já mencionadas, o segundo outorgante continuará a tratar do café como colono recebendo como pagamento anual e da colheita dos fru-

63 Livro de Notas n. 32. fls. 95. 2. ${ }^{\circ}$ Ofício Civil de Araraquara. 19/06/1928.

64 Livro de Notas n.111, fls. 18. 2. Ofício Civil de Franca. 28/07/1923.

65 Livro de Notas n. 99. fls. 95. 2. ${ }^{\circ}$ Ofício Civil de São Carlos. 24/01/1928.

66 Livro de Notas n. 61, fls. 21. 2. Ofício Civil de Pirajuí. 02/02/1932. 
tos o preço corrente na ocasião, até se pagar com os frutos produzidos, ficando então já a metade dos frutos do quinto ano destinada a esse pagamento. ${ }^{67}$

Esses trechos evidenciam as dificuldades vivenciadas pelos trabalhadores no momento de liquidação das escrituras. Geralmente, os valores monetários envolvidos eram "acertados" no final dos quatro anos de contrato, pois os fazendeiros tinham que verificar, depois desse período, o número de cafeeiros formados, se as lavouras tinham sido bem cuidadas etc., e, em caso de má formação, oriunda de maus tratos, era necessário descontar os valores das falhas ou aplicar as multas que penalizavam os trabalhadores que não haviam desempenhado as tarefas adequadamente.

Por conta da fiscalização, e também para saldar seus débitos quando as lavouras já fossem produtivas, as somas de dinheiro a serem despendidas, no caso da existência de saldos, acumulavam-se no final do contrato, além do mais, o pagamento pelo trabalho estaria submetido diretamente às condições de preço e de produtividade de um determinado ano. Já prevendo situações desfavoráveis, os fazendeiros se protegiam ao estipular cláusulas que previam a prorrogação contratual, o que certamente era muito positivo, uma vez que os ganhos da empreitada, os valores pagos por cada cova formada seriam reduzidos a salários de colonos e/ou pagos com a produção de café. De certo modo, o contrato já previa o "calote", resguardando os interesses dos fazendeiros.

Por outro lado, quando por algum motivo o fazendeiro quisesse se livrar de algum trabalhador, poderia acionar as cláusulas de "dispensa". Observemos o trecho que se segue:

o outorgado que se recusar ao cumprimento de qualquer das cláusulas deste contrato, a fazenda as fará por conta do mesmo, cobrando-lhe ainda a multa que couber, e no caso de reincidência de abusos ou de insubordinação à disciplina da fazenda poderá ser dispensado sem remuneração nenhuma pelos serviços feitos até ali e obrigado a desocupar a casa imediatamente. ${ }^{68}$

A fiscalização dos serviços cabia ao capataz da fazenda, sendo ele o responsável pelo bom andamento da formação das lavouras, os julgamentos de conduta, a recepção de visitas nas colônias etc. Entretanto, cabe salientar que, se por um lado as escrituras possibilitavam a prorrogação do contrato em caso de atraso nos pagamentos, por outro, estabeleciam a possibilidade de um rompimento unilateral por parte do fazendeiro, bastando para isso que se entendesse que uma determinada atividade não tivesse sido realizada a contento, uma vez que os critérios de fiscalização, definidos em contrato, eram extremamente subjetivos, podendo ser o contratado "demitido" por qualquer motivo: um número excessivo de porcos, a utilização de terras para pastos não definida em contrato, a julgada "inaptidão" para o trabalho, a preguiça, o excessivo consumo de álcool, enfim, uma ampla gama de justificativas que poderiam ser utilizadas indiscriminadamente pelo fazendeiro, explicitando uma correlação de forças extremamente desigual que se efetivava nesse tipo de escritura cartorial.

67 Livro de Notas n. 03, fls. 79. 2. ${ }^{\circ}$ Ofício Civil de Pirajuí. 08/04/1922.

68 Livro de Notas n. 35, fls. 56. 2. ${ }^{\circ}$ Ofício Civil de Pirajuí. 28/11/1927. 


\section{Considerações Finais}

Os exemplos e situações aqui considerados revelam mecanismos de exploração dos trabalhadores rurais sediados na cafeicultura paulista até então não considerados pela bibliografia sobre o tema, indicando para o fato de que as relações de trabalho travadas eram mais deletérias aos trabalhadores do que se supunha. Tal revelação decorre da utilização de uma fonte documental até então pouco utilizada - os Livros Cartoriais. Nossos apontamentos corroboram a tese de uma melhor remuneração pelo trabalho existente nas zonas novas (fronteira) em função não somente das rendas não monetárias advindas de um maior espaço para as culturas intercalares, como também dos pagamentos em dinheiro pela formação de lavoura, mais recorrentes nessas regiões. Por outro lado, vimos que no conjunto das regiões paulistas de cafeicultura foram colocadas em prática estratégias de rebaixamento dos ganhos dos trabalhadores no que se refere às suas produções de café e de gêneros alimentícios. Há que se considerar que tais estratégias foram aplicadas num cenário marcado por hierarquias sociais e políticas extremamente rígidas que esvaziavam qualquer sentido de igualdade pressuposto entre as partes contratantes. As formas de exploração aqui desveladas assinalam para a perpetuação dos desnivelamentos da sociedade brasileira, reiterando a desigualdade no tempo e no espaço. 


\section{ANEXOS}

Mapas - regiões e municípios pesquisados em Faleiros (2010). São Paulo/Brasil.

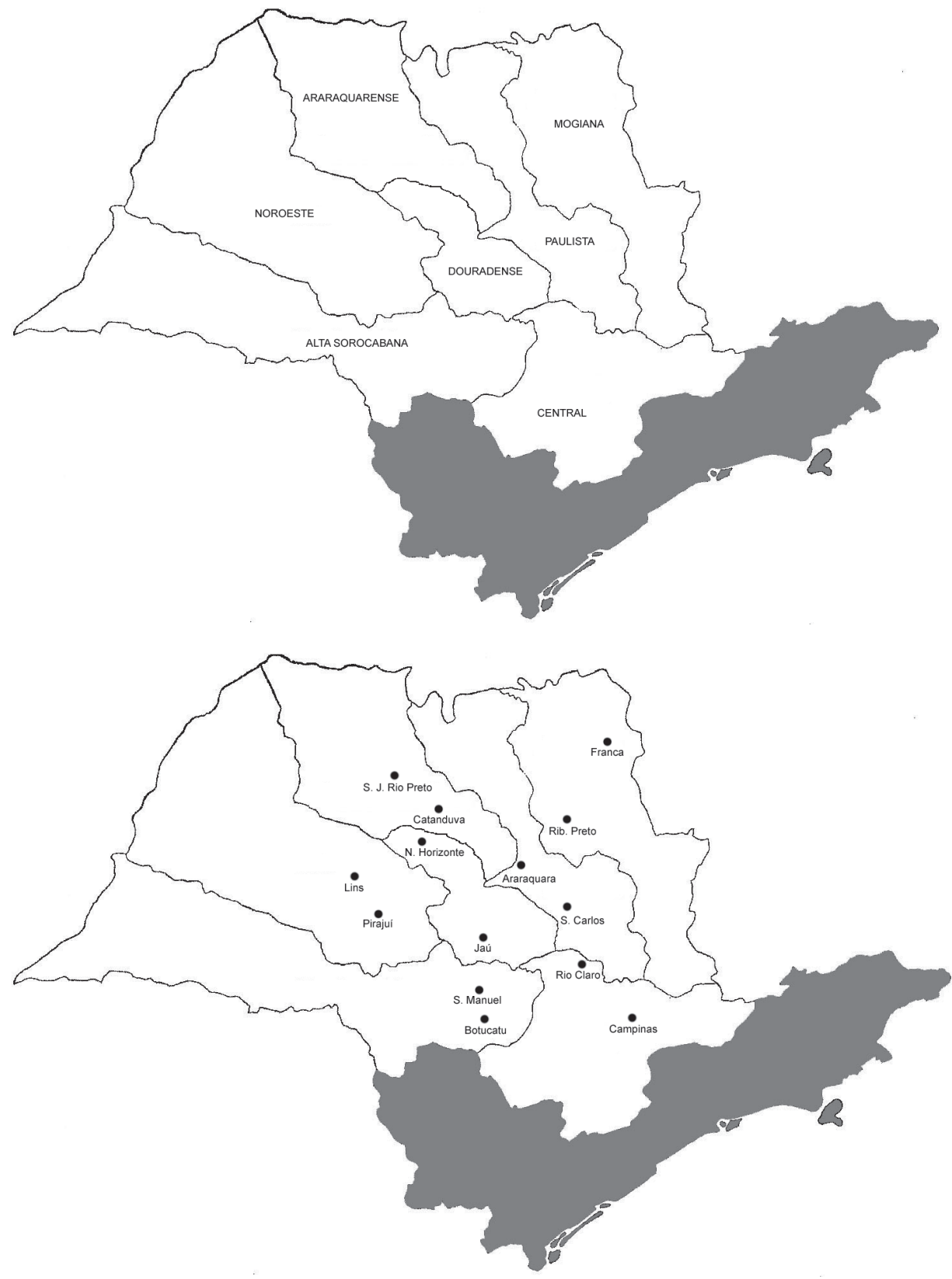

Fonte: Faleiros (2010). 